\title{
HUBUNGAN STRES DENGAN TIMBULNYA KECENDERUNGAN GANGGUAN MENTAL EMOSIONAL PADA MAHASISWA FAKULTAS KEDOKTERAN UNIVERSITAS PEMBANGUNAN NASIONAL "VETERAN" JAKARTA
}

\author{
THE RELATIONSHIP OF STRESS AND THE TENDENCY TO DEVELOP MENTAL EMOTIONAL \\ DISORDER AMONG STUDENTS OF UNIVERSITAS PEMBANGUNAN NASIONAL "VETERAN" \\ JAKARTA FACULTY OF MEDICINE
}

\author{
Joshua Sebastian Pratama Sondakh, Ria Maria Theresa ${ }^{2}$ \\ 1. Program Studi Kedokteran Program Sarjana, Fakultas Kedokteran UPN “Veteran” Jakarta \\ 2. Fakultas Kedokteran UPN "Veteran" Jakarta \\ Jl. RS Fatmawati, Pondok Labu, Jakarta Selatan 12450, Telp. (021) 7656971 \\ E-mail : sebastian.sondakh@gmail.com
}

\begin{abstract}
ABSTRAK
Mahasiswa fakultas kedokteran rentan terhadap berbagai stresor selama masa belajarnya. Enam domain stresor yang paling berpengaruh adalah akademik, hubungan interpersonal dan intrapersonal, kegiatan belajar mengajar, hubungan sosial, dorongan dan motivasi serta aktivitas kelompok. Pada tingkat optimal, stres bersifat menguntungkan, tetapi stres yang berlebihan menimbulkan respon stres. Tanpa intervensi, respon stres dapat menetap dan menimbulkan gejala gangguan mental emosional (GME). Dampak jangka pendek gejala ini adalah penurunan produktivitas dan kualitas hidup, sedangkan dampak jangka panjangnya adalah gejala menetap hingga mahasiswa lulus dan berpengaruh terhadap penanganan pasien. Tujuan penelitian ini adalah mengetahui hubungan antara stres setiap domain dengan timbulnya kecenderungan GME. Desain penelitian berupa analisis observasional dengan metode cross-sectional pada 80 responden sebagai sampel yang ditentukan dengan teknik purposive sampling. Data dikumpulkan dengan pengisian kuisioner Medical Student Stress Questionnaire (MMSQ) untuk menilai tingkat stres dan Self-Reporting Questionnaire (SRQ-20) untuk menilai kecenderungan GME. Hasil penelitian menunjukkan terdapat hubungan yang signifikan antara stres dengan timbulnya kecenderungan GME pada mahasiswa Fakultas Kedokteran UPN “Veteran” Jakarta angkatan 2018 dengan peluang paling besar diakibatkan stresor motivasi dan dorongan yaitu 7,39 kali ( $p=0,022 ; 95 \% C I=1,34-40,79)$
\end{abstract}

Kata Kunci: gangguan mental emosional; mahasiswa kedokteran; MSSQ; SRQ-20; stres

\begin{abstract}
Medical students are vulnerable to various stressors during their studies. Six most influential domain of stressors are academic, interpersonal and intrapersonal relationships, teaching and learning, social relations, drive and desire and group activities. At optimal level, stress is beneficial, but excessive stress causes stress response. Without intervention, it can persist and cause symptoms of mental emotional disorders. Short-term impacts include decrease in productivity and quality of life, while long-term ones include symptoms that last until students graduate and may influence patient care. The purpose of this study was to determine the relationship between stress of each domain with the tendency to develop mental emotional disorders. This research was an observational analysis with cross-sectional method on 80 respondents as a sample, determined by purposive sampling technique. Data was collected by filling out the Medical Student Stress Questionnaire (MMSQ) to assess stress levels and Self-Reporting Questionnaire (SRQ-20) to assess the tendency of mental emotional disorders. Results showed that there was a significant relationship between stress and the tendency to develop mental emotional disorders among students of Universitas Pembangunan Nasional "Veteran" Jakarta Faculty of Medicine batch 2018, and drive and desire domain was 7.39 times more likely to cause it ( $p=0.022 ; 95 \% C I=1.34-40.79)$.
\end{abstract}

Keywords: medical student; mental emotional disorder; MSSQ; SRQ-20; stress 


\section{PENDAHULUAN}

Pendidikan kedokteran hampir selalu dihubungkan dengan tingkat stres yang tinggi. Menurut Dahlin, tingginya tingkat stres dapat memberikan dampak negatif pada fungsi kognitif serta kemampuan belajar, padahal rata-rata beban belajar mahasiswa kedokteran lebih berat karena jadwal perkuliahannya lebih padat serta masa studi yang lebih panjang. ${ }^{1,2}$ Tingkat stres ini sangat bergantung pada kurikulum pendidikan, sistem ujian dan kondisi kampus. $^{3}$ Ekspektasi terhadap mahasiswa kedokteran juga sangat tinggi, mengingat sulitnya diterima di fakultas kedokteran di Indonesia. Selain itu, mahasiswa kedokteran lebih beresiko terpapar terhadap penyakit dan kematian. Dokter adalah profesi yang berhubungan dengan nyawa manusia, sehingga mahasiswa kedokteran secara tidak langsung dituntut untuk tidak berbuat kesalahan atau meminimalisir kesalahan sekecil mungkin.

Kombinasi berbagai hal di atas menyebabkan tuntutan yang besar dalam segi akademis terhadap mahasiswa kedokteran dan menjadi pencetus stres. Di samping akademik, terdapat faktor-faktor non-akademik seperti hubungan sosial dan hubungan intrapersonal yang dapat mencetuskan stres. Beberapa penelitian telah mengemukakan bahwa mahasiswa kedokteran memiliki tingkat stres yang lebih tinggi secara signifikan dibandingkan mahasiswa dari fakultas lain. ${ }^{4}$

Stres dapat didefinisikan sebagai kondisi atau perasaan yang dialami ketika ekspektasi pada seseorang melebihi kemampuan yang dimiliki. Stres dapat mempengaruhi pencapaian akademik mahasiswa kedokteran karena mengkibatkan turunnya konsentrasi, rasionalitas dalam pengambilan keputusan dan berkaitan erat dengan depresi. ${ }^{3}$ Stres yang dialami secara berkelanjutan dapat menyebabkan berkembangnya gangguan mental emosional (GME). Keadaan ini diperparah dengan fakta bahwa usia rata-rata mahasiswa cenderung beresiko mengalami GME seperti depresi, ansietas dan komorbiditas kejiwaan lainnya. ${ }^{4}$ GME berdampak pada performa mahasiswa, mulai dari kesulitan dalam bidang akademik, terisolasi dari teman sebaya hingga hendaya fisik yang signifikan. Banyak penelitian juga mengungkapkan bahwa subjek penelitian mengeluhkan penurunan kualitas hidup. ${ }^{5}$ Selain konsekuensi di atas, juga dapat terjadi mekanisme koping yang tidak diinginkan seperti kekerasan, konsumsi alkohol, hingga melukai diri sendiri (self-harm). ${ }^{5}$

Pendidikan kedokteran bertujuan untuk menghasikan dokter dengan ilmu dan keterampilan yang mumpuni, sehingga dapat melakukan penatalaksanaan pasien dengan baik, ikut mengembangkan ilmu kedokteran dan menjaga bahkan meningkatkan taraf kesehatan masyarakat. ${ }^{3}$ Mahasiswa kedokteran adalah salah satu bakal tenaga profesional yang penting bagi masa depan. Timbulnya masalah kejiwaan pada mahasiswa dapat menyebabkan turunnya produktivitas dan kualitas hidup, menimbulkan kendala dalam proses pembelajaran dan berpotensi menyebabkan perawatan pasien menjadi tidak adekuat. ${ }^{3}$ Deteksi awal dan pencegahan dini menjadi sangat penting untuk mencegah berbagai efek negatif yang mungkin saja muncul apabila mahasiswa menghadapi masalah kejiwaan.

GME pada mahasiswa kedokteran dapat menetap hingga kelulusan jika tidak dideteksi dan diatasi sejak dini. Hal ini dapat mengurangi jumlah dokter kompeten lulusan universitas, sehingga berdampak pada tercorengnya nama baik almamater, praktik kedokteran yang buruk, dan berkurangnya tingkat kepercayaan pasien pada dokter. Oleh karena itu, peneliti tertarik untuk meneliti hubungan stres dengan timbulnya kecenderungan GME pada mahasiswa FK UPN "Veteran" Jakarta.

\section{METODE PENELITIAN}

\section{Desain Penelitian}

Penelitian ini bersifat analitik observasional dengan variabel bebas berupa 
tingkat stres secara umum maupun setiap domain stresor dan variabel terikat berupa kecenderungan GME. Pendeketan yang digunakan adalah pendekatan potong lintang.

\section{Populasi dan Sampel}

Populasi penelitian adalah seluruh mahasiswa FK UPN "Veteran" Jakarta angkatan 2018. Sampel adalah mahasiswa angkatan 2018 yang memenuhi kriteria inklusi, yaitu bersedia mengisi kuesioner penelitian dan telah mengikuti perkuliahan minimal 6 bulan dengan kehadiran minimal $80 \%$. Kriteria eksklusi dalam penelitian ini yaitu responden yang menggunakan NAPZA maupun obat-

obatan psikorfarmaka serta responden yang menunjukkan gejala gangguan berat sehingga tidak dapat mengisi kuesioner secara mandiri.

Sampel diambil dengan teknik purposive sampling dan dihitung dengan rumus besar sampel beda proporsi. Jumlah sampel yang diambil sebesar 80 responden.

\section{Pengumpulan Data}

Data yang digunakan dalam penelitian ini merupakan data primer. Data diperoleh langsung dari hasil wawancara responden. Tingkat stres secara umum dan setiap domain stresor diukur dengan Medical Student Stress Questionnaire, sedangkan kecenderungan GME diukur dengan Self-Reporting Questionnaire-20. Tingkat stres dibagi menjadi ringan-sedang dan berat-sangat berat. Kecenderungan GME dikelompokkan menjadi positif dan negatif dengan nilai cut-off $\geq 6$.

\section{Analisis Data}

Pengolahan data dilakukan dengan uji Chi-square untuk analisis bivariat. Tingkat kemaknaan 0.05. Uji alternatif bivariat menggunakan uji Fisher. Uji multivariat dilakukan dengan regresi logistik berganda. Data diolah dengan aplikasi SPSS.

\section{HASIL PENELITIAN}

\section{Karakteristik Responden}

Karakteristik sampel penelitian meliputi distribusi usia, jenis kelamin, tingkat stres secara umum, tingkat stres enam domain stresor yaitu: academic related stressors (ARS); interpersonal and intrapersonal related stressors (IRS); teaching and learning related stressors (TLRS); social related stressors (SRS); drive and desire related stressors (DRS) dan group activity related stressors (GARS), distribusi kecenderungan GME, distribusi gejala GME pada seluruh responden serta distribusi gejala GME pada responden dengan kecenderungan positif.

Tabel 1. Karakteristik Responden

\begin{tabular}{lcc}
\hline Karateristik & Frekuensi & Persentase (\%) \\
\hline Usia (tahun) & 71 & 88,8 \\
$\leq 19$ & $\underline{9}$ & $\underline{11,3}$ \\
$>19$ & 17 & 21,3 \\
\cline { 1 - 1 } Jenis Kelamin & 63 & 78,8 \\
Laki-laki & $\underline{80}$ & $\underline{100}$ \\
Perempuan & & \\
Total & &
\end{tabular}

Distribusi usia responden menunjukkan bahwa sebagian besar responden berusia kurang dari sama dengan 19 tahun sebanyak 71 orang $(88,8 \%)$ dan lebih dari 19 tahun sebanyak 9 orang $(11,3 \%)$. Responden lebih banyak berjenis kelamin perempuan dibandingkan laki-laki dengan jumlah 63 orang $(78,8 \%)$.

\section{Hasil Analisis Univariat}

Tingkat stres dibagi menjadi ringansedang dan berat-sangat berat berdasarkan ada tidaknya distres yang ditimbulkan. Dari analisis univariat gambaran tingkat stres secara umum didapatkan sebanyak 52 orang $(65 \%)$ memiliki tingkat stres ringan-sedang dan sebanyak 28 orang $(35 \%)$ memiliki tingkat stres berat-sangat berat. Pada domain ARS, sebanyak 45 orang $(56,3 \%)$ mengalami stres ringan-sedang dan 35 orang $(43,8 \%)$ mengalami stres berat-sangat berat. Pada domain IRS, 60 orang $(75 \%)$ mengalami stres ringan-sedang dan 20 orang (25\%) mengalami stres berat-sangat berat. Pada domain TLRS, 62 orang $(77,5 \%)$ mengalami stres ringansedang dan 18 orang $(22,5 \%)$ mengalami stres berat-sangat berat. Pada domain SRS, 68 orang 
(85\%) mengalami stres ringan-sedang dan 12 orang $(15 \%)$ mengalami stres berat-sangat berat. Pada domain DRS, 64 orang (80\%) mengalami stres ringan-sedang dan 16 orang $(20,0 \%)$ mengalami stres berat-sangat berat pada. Pada domain GARS, 71 orang $(88,8 \%)$ mengalami stres ringan-sedang dan 9 orang $(11,3 \%)$ mengalami stres berat-sangat berat.

Tabel 2. Tingkat Stres

\begin{tabular}{|c|c|c|}
\hline Variabel & Frekuensi & Persentase (\%) \\
\hline \multicolumn{3}{|c|}{ Tingkat Stres Umum } \\
\hline Berat-sangat berat & 28 & 35 \\
\hline Ringan-sedang & 52 & 65 \\
\hline
\end{tabular}

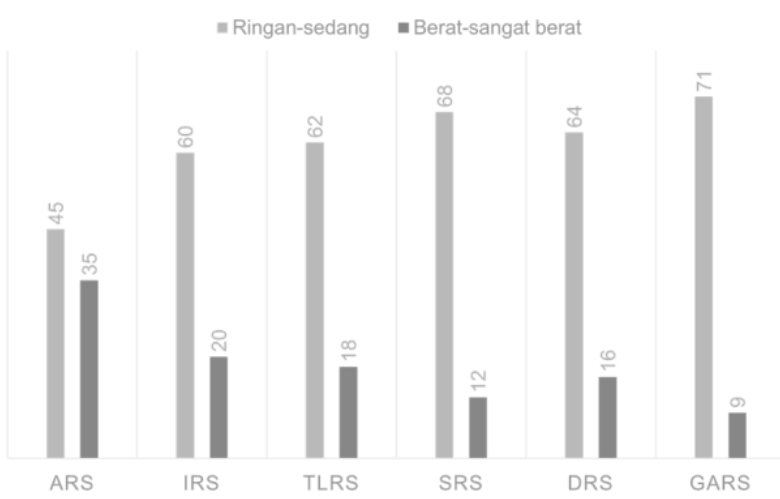

Gambar 1. Tingkat Stres Setiap Domain

Dari hasil analisis univariat terhadap kecenderungan GME didapatkan sebanyak 38 orang $(47,5 \%)$ memiliki kecenderungan GME dan 42 orang $(52,5 \%)$ tidak memiliki kecenderungan GME. Dari 80 responden yang mengisi kuesioner didapatkan 56 orang $(70 \%)$ yang mengeluhkan setidaknya satu gejala ansietas; 40 orang $(50 \%)$ yang mengeluhkan setidaknya satu gejala depresi; 42 orang $(52,5 \%)$ yang mengeluhkan setidaknya satu gejala penurunan kognitif; 48 orang $(60 \%)$ yang mengeluhkan setidaknya satu gejala somatik dan 61 orang $(76,3 \%)$ yang mengeluhkan setidaknya satu gejala penurunan energi. Dari 38 orang responden yang positif memiliki kecenderungan GME, didapatkan 36 orang $(94,7 \%)$ yang mengeluhkan setidaknya satu gejala ansietas; 34 orang $(89,5 \%)$ yang mengeluhkan setidaknya satu gejala depresi; 31 orang $(81,6 \%)$ yang mengeluhkan setidaknya satu gejala penurunan kognitif; 33 orang $(86,8 \%)$ yang mengeluhkan setidaknya satu gejala somatik dan 37 orang $(97,4 \%)$ yang mengeluhkan setidaknya satu gejala penurunan energi. Responden dengan kecenderungan GME positif mengeluhkan rata-rata sepuluh gejala dalam SRQ-20.

Tabel 3. Kecenderungan GME

\begin{tabular}{lcc}
\hline \multicolumn{1}{c}{ Variabel } & Frekuensi & Persentase (\%) \\
\hline Kecenderungan GME & & \\
Ya & 35 & 43,8 \\
Tidak & 45 & 56,3 \\
Total & 80 & 100 \\
\hline
\end{tabular}

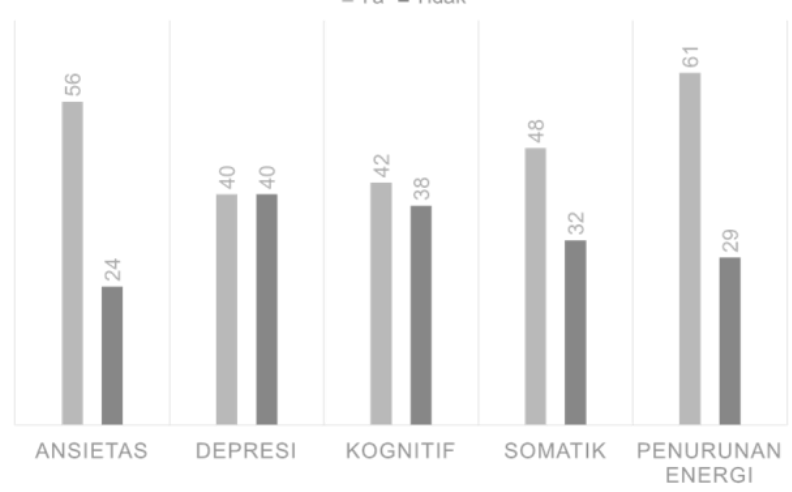

Gambar 2. Distribusi Gejala GME

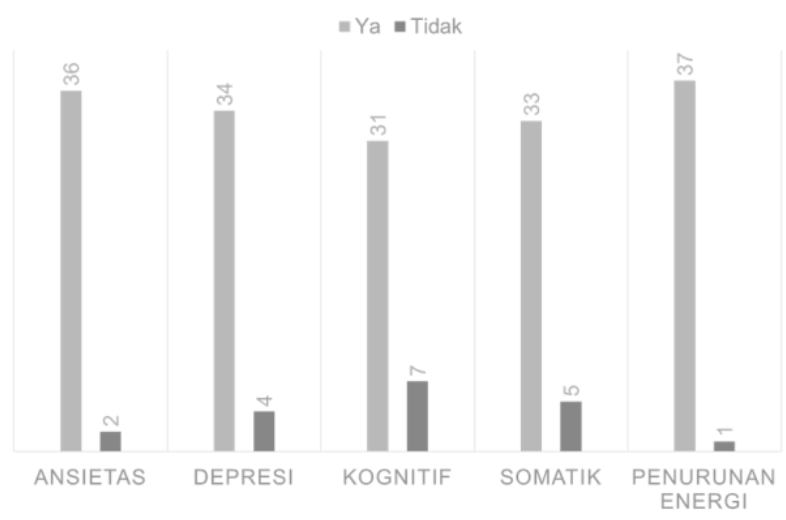

Gambar 3. Distribusi Gejala GME pada Responden dengan Kecenderungan GME Positif

\section{Hasil Analisis Bivariat}

Hasil analisis bivariat hubungan tingkat stres secara umum maupun setiap domain stresor dapat dilihat pada tabel 3. Dari uji chi-square didapatkan hubungan yang signifikan antara tingkat stres berat-sangat 
berat secara umum maupun setiap domain stresor dengan timbulnya kecenderungan GME. Variabel GARS dianalisis dengan uji alternatif Fisher. Variabel independen dengan OR paling tinggi adalah tingkat stres secara umum sebesar 25,00 (95\%CI=6,47-96,64).

Tabel 4. Hubungan Stres Setiap Domain Stresor dengan Kecenderungan Gangguan Mental Emosional

\begin{tabular}{|c|c|c|c|c|}
\hline \multirow{2}{*}{$\begin{array}{l}\text { Domain } \\
\text { Stresor }\end{array}$} & \multicolumn{2}{|c|}{ GME } & \multirow{2}{*}{ P-Value } & \multirow{2}{*}{$\begin{array}{c}\text { OR } \\
(95 \% \mathrm{CI}) \\
\end{array}$} \\
\hline & Ya & Tidak & & \\
\hline \multicolumn{5}{|l|}{ Umum } \\
\hline Berat- & 25 & $s$ & \multirow{3}{*}{0,001} & \multirow{3}{*}{$\begin{array}{l}25,00 \\
(6,47- \\
96,64)\end{array}$} \\
\hline $\begin{array}{l}\text { sangat } \\
\text { berat }\end{array}$ & & & & \\
\hline $\begin{array}{l}\text { Ringan- } \\
\text { sedang }\end{array}$ & 13 & 39 & & \\
\hline \multicolumn{5}{|l|}{ ARS } \\
\hline Berat- & 27 & o & \multirow{3}{*}{0,001} & \multirow{3}{*}{$\begin{array}{c}10,43 \\
(3,68- \\
29,56)\end{array}$} \\
\hline $\begin{array}{l}\text { sangat } \\
\text { berat }\end{array}$ & & & & \\
\hline $\begin{array}{l}\text { Ringan- } \\
\text { sedang }\end{array}$ & 11 & 34 & & \\
\hline \multicolumn{5}{|l|}{ IRS } \\
\hline Berat- & 17 & $J$ & \multirow{3}{*}{0,001} & \multirow{3}{*}{$\begin{array}{l}10,52 \\
(2,76- \\
40,08)\end{array}$} \\
\hline $\begin{array}{l}\text { sangat } \\
\text { berat }\end{array}$ & & & & \\
\hline $\begin{array}{l}\text { Ringan- } \\
\text { sedang }\end{array}$ & 21 & 39 & & \\
\hline \multicolumn{5}{|l|}{ TLRS } \\
\hline Berat- & 16 & 2 & \multirow{4}{*}{0,001} & \multirow{3}{*}{$\begin{array}{l}14,55 \\
(3,06- \\
69,17)\end{array}$} \\
\hline $\begin{array}{l}\text { sangat } \\
\text { berat }\end{array}$ & & & & \\
\hline $\begin{array}{l}\text { Ringan- } \\
\text { sedang }\end{array}$ & 22 & 40 & & \\
\hline \multicolumn{4}{|l|}{ SRS } & \\
\hline Berat- & 11 & 1 & \multirow{3}{*}{0,001} & \multirow{3}{*}{$\begin{array}{c}16,70 \\
(2,04- \\
136,95)\end{array}$} \\
\hline $\begin{array}{l}\text { sangat } \\
\text { berat }\end{array}$ & & & & \\
\hline $\begin{array}{l}\text { Ringan- } \\
\text { sedang }\end{array}$ & 27 & 41 & & \\
\hline \multicolumn{5}{|l|}{ DRS } \\
\hline $\begin{array}{l}\text { Berat- } \\
\text { sangat }\end{array}$ & 14 & 2 & \multirow{4}{*}{0,001} & \multirow{3}{*}{$\begin{array}{l}11,67 \\
(2,44- \\
55,83)\end{array}$} \\
\hline berat & & & & \\
\hline $\begin{array}{l}\text { Ringan- } \\
\text { sedang }\end{array}$ & 24 & 40 & & \\
\hline \multicolumn{4}{|l|}{ GARS } & \\
\hline Berat- & 8 & 1 & \multirow{3}{*}{0,011} & \multirow{3}{*}{$\begin{array}{c}10,93 \\
(1,30- \\
92,14)\end{array}$} \\
\hline $\begin{array}{l}\text { sangat } \\
\text { berat }\end{array}$ & & & & \\
\hline Ringan- & 30 & 41 & & \\
\hline sedang & & & & \\
\hline
\end{tabular}

\section{Hasil Analisis Multivariat}

Hasil Analisis multivariat dapat dilihat pada tabel 4. Dari seluruh domain stresor didapatkan tiga domain yang memiliki pengaruh signifikan. Domain stresor ARS, IRS dan DRS bermakna secara statistik terhadap timbulnya kecenderungan GME. Dari ketiga domain tersebut, domain DRS atau stresor dorongan dan keinginan merupakan stresor yang paling dominan. Tingkat stres berat sangat berat pada domain ini berpeluang 7,39 kali lebih tinggi untuk menimbulkan kecenderungan GME.

Tabel 5. Analisis Multivariat Antar Variabel dan Kecenderungan GME

\begin{tabular}{lccc}
\hline Variabel & P-Value & OR & OR $(\mathbf{9 5 \%}$ CI) \\
\hline ARS & 0.006 & 5,21 & $1,59-17,05$ \\
IRS & 0.053 & 4,48 & $0,98-20,53$ \\
DRS & 0.022 & 7,39 & $1,34-40,79$ \\
\hline
\end{tabular}

\section{PEMBAHASAN}

Berdasarkan tabel 2 didapatkan bahwa kebanyakan responden mengalami tingkat stres ringan-sedang $(65 \%)$. Persentase ini tidak jauh berbeda beberapa penelitian mengenai tingkat stres yang dilakukan di beberapa universitas lain., ${ }^{2,6}$ Perbedaan angka persentase dapat diakibatkan perbedaan karakteristik responden yang dijadikan sampel di masing- masing lokasi penelitian, seperti kepribadian dan kemampuan adapatasi atau koping. Menurut Sharif dkk., faktor kepribadian akan berpengaruh dalam bagaimana seseorang mengolah stresor yang dihadapi. $^{6}$ Strategi koping menentukan seberapa besar pengaruh stres terhadap keadaan fisik dan mental seseorang, karena mekanisme koping mempengaruhi berbagai fungsi fisiologis tubuh termasuk neuroendokrin yang menimbulkan respon stres. $^{5,7}$ Terlepas dari berbagai persentase tingkat stres, semua hasil penelitian konsisten melaporkan tingkat stres ringan-sedang adalah yang paling umum dialami mahasiswa fakultas kedokteran., ${ }^{2,6}$

Hasil analisis univariat pada variabel tingkat stres berdasarkan domain stresor mendapati domain stresor dengan tingkat 
stress berat-sangat berat paling tinggi adalah academic related stressors (ARS), diikuti intrapersonal and interpersonal related stressors (IRS), teaching and learning related stressors (TLRS), drive and desire related stressors (DRS), social related stressors (SRS) dan group activity related stressors (GARS). Hasil yang sejalan, dengan perbedaan urutan domain hanya pada domain SRS sebagai urutan terakhir setelah GARS dilaporkan sebuah penelitian di unversitas lain di Indonesia. ${ }^{2}$ Hasil yang didapatkan juga sejalan dengan penelitian di Malaysia yang melaporkan bahwa sepuluh sumber stres terbanyak didominasi oleh stresor akademik dan dorongan terhadap diri sendiri. ${ }^{8}$

Banyaknya bahan yang harus dipelajari, deadline dan kurangnya waktu review serta nilai yang kurang baik menyebabkan stres tingkat sedang hingga berat. ${ }^{8}$ Hasil penelitian di Arab Saudi juga mendapatkan bahwa sumber stres terbesar $(60,3 \%)$ mahasiswa kedokteran berasal dari tekanan akademiknya. ${ }^{1}$ Hal ini menjelaskan tingginya persentase stres pada domain ARS sebagai domain stresor utama. Sebaliknya, dari beberapa penelitian tersebut domain GARS selalu berada di urutan terakhir atau hampir akhir. Hal ini menunjukkan bahwa aktivitas kelompok secara konsisten menyebabkan lebih sedikit stres berat-sangat berat dibandingkan domain stresor lainnya.

Hasil analisis univariat terhadap kecenderungan GME menunjukkan bahwa terdapat 38 orang mahasiswa $(47,5 \%)$ yang memiliki kecenderungan GME dan 42 orang mahasiswa $(52,5 \%)$ yang tidak memiliki kecenderungan GME. Jumlah mahasiswa tanpa kecenderungan GME lebih banyak apabila dibandingkan dengan mahasiswa yang memiliki kecenderungan tersebut.

Beberapa penelitian menggunakan instrumen GHQ melaporkan prevalensi GME yang tidak jauh berbeda dengan hasil penelitian ini. Sebuah penelitian di Inggris melaporkan sekitar sepertiga responden mahasiswa kedokteran mengalami GME. $^{8}$ Penelitian lainnya di Malaysia melaporkan masing-masing $41,9 \%$ dan $46,2 \%$ mahasiswa mengalami GME. ${ }^{9,10}$

Gejala-gejala GME yang dikeluhkan responden berdasarkan SRQ-20 yaitu gejala ansietas, depresi, penurunan kognitif, gejala somatik dan penurunan energi. Gejala yang paling banyak dikeluhkan responden yaitu gejala penurunan energi $(76,3 \%)$, diikuti ansietas (70\%), somatik (60\%), gangguan

kognitif $(52,5 \%)$ dan depresi (50\%). Urutan frekuensi gejala ini sedikit berbeda pada responden dengan kecenderungan GME. Responden yang positif memiliki kecenderungan GME (38 orang) tetap paling banyak mengeluhkan gejala penurunan energi $(97,4 \%)$ dan ansietas $(94,7 \%)$, tetapi lebih banyak yang mengeluhkan gejala depresi $(89,5 \%)$ dibandingkan gejala somatik $(86,8 \%)$ dan gangguan kognitif $(81,6 \%)$.

Responden yang positif memiliki kecenderungan GME tidak seluruhnya mengeluhkan setiap gejala GME. Sebaliknya, responden yang tidak memiliki kecenderungan GME juga dapat mengeluhkan sebagian gejala GME walaupun tidak sampai melewati batas nilai cut-off. Hal ini dikarenakan keterbatasan kuesioner berupa sensitivitas dan spesifisitas. Kuesioner tidak dapat menggantikan peran dokter atau psikiater dalam mendiagnosis suatu masalah kejiwaan. Diagnosis tersebut memerlukan kriteria diagnosis baku seperti DSM-V dan pertimbangan ahli kejiwaan atau psikiater. Seseorang tidak dapat dikatakan menderita GME hanya dengan mengeluhkan satu atau beberapa gejala GME yang dianggap positif pada kuesioner skrining. Bahkan, apabila terdapat sejumlah gejala GME hingga melewati batas nilai cut-off, orang tersebut hanya dapat dikatakan memiliki kecenderungan GME.

Berdasarkan analisis chi-square terdapat hubungan yang signifikan antara tingkat stresor secara umum maupun setiap domain stresor dengan variabel dependen yaitu kecenderungan GME. Tingkat stres beratsangat berat secara umum berpeluang 25,00 kali untuk timbul kecenderungan GME. Belum ada penelitian terdahulu yang meneliti 
hubungan stres dengan timbulnya kecenderungan GME pada mahasiswafakultas kedokteran. Akan tetapi, beberapa penelitian lain yang meneliti hubungan stres dengan timbulnya kecenderungan GME pada populasi profesi tertentu menemukan hubungan yang signifikan di antara keduanya. ${ }^{11,12}$

Sebaliknya, hasil analisis multivariat hanya menunjukkan tiga domain stresor yang signifikan yaitu ARS, IRS dan DRS. Hal ini menunjukkan bahwa masing-masing domain stresor secara individual memiliki hubungan yang bermakna dengan timbulnya kecenderungan gangguan emosional, tetapi hanya domain ARS, IRS dan DRS yang pengaruhnya tetap signifikan apabila interaksi antar keenam domain stresor turut diperhatikan.

Sekolah kedokteran merupakan suatu fase yang memiliki tuntutan besar dalam karir medis seorang dokter mengingat banyaknya materi dan jam pembelajaran yang harus ditempuh. ${ }^{13}$ Selain berhadapan dengan stresor umum dalam kehidupan sehari-hari, mahasiswa kedokteran harus berhadapan dengan pengetahuan medis yang kompleks, tanggungan beban finansial, waktu senggang yang lebih sedikit dibandingkan mahasiswa pada umumnya dan pilihan karir yang terbatas di akhir masa belajarnya. ${ }^{13}$ Banyaknya stresor tersebut akan menimbulkan respon stres, yang dalam jangka panjang dapat menetap dan berpotensi menimbulkan gejala-gejala GME. Hal ini turut didukung oleh penelitian systematic review yang dilakukan di Asia, di mana mahasiswa fakultas kedokteran di Asia cenderung rentan terhadap masalah kesehatan jiwa dan 52,7\% dari mahasiswa tersebut menghadapi stres yang signifikan selama berkuliah di fakultas kedokteran. ${ }^{14}$ Selain itu, stresor yang semakin meningkat dapat memperburuk respon individu yang telah lebih dulu memiliki kecenderungan GME. ${ }^{15}$

\section{Domain ARS}

Sumber utama stres akademik dengan tingkat berat-sangat berat yang dirasakan mahasiswa FK UPN "Veteran" Jakarta adalah banyaknya dan sulitnya materi yang harus dipelajari, kurangnya waktu review, tertinggal dalam belajar dan ujian. Sistem pembelajaran kurikulum berbasis kompetensi (KBK) dalam Kurikulum Inti Pendidikan Dokter (KIPDI) membagi materi kuliah ke dalam tujuh belas blok yang berlangsung selama 4-7 minggu setiap bloknya. ${ }^{16}$ Dalam kurun waktu tersebut mahasiswa dituntut untuk mempelajari ilmu dasar (anatomi, fisiologi, histologi) dan klinis (penyakit berdasarkan Standar Kompetensi Dokter Indonesia). Ujian dilaksanakan satu minggu setelah akhir jadwal perkuliahan sehingga tidak ada jeda waktu di antaranya. Hal ini menyebabkan mahasiswa juga merasakan tekanan deadline sebagai salah satu stresor yang memperberat.

Pencapaian akademik adalah salah satu faktor terjadinya masalah kejiwaan. ${ }^{3}$ Tuntutan beban belajar berupa pengetahuan medis yang kompleks, jadwal perkuliahan yang padat dan masa studi yang panjang dapat menyebabkan stres yang signifikan. ${ }^{2,13}$ Proses yang berat selama pendidikan menyebabkan mahasiswa kedokteran rentan terhadap timbulnya masalah kejiwaan. ${ }^{3}$ Tanpa mekanisme koping dan dukungan sosial yang tepat, stres akademik dapat menyebabkan kecenderungan GME. ${ }^{8}$

\section{Domain IRS}

Sumber utama stres dari hubungan interpersonal dan intrapersonal dengan tingkat berat-sangat berat yang dirasakan mahasiswa FK UPN "Veteran" Jakarta adalah konflik dengan dosen, perkataan dosen yang menyinggung perasaan serta motivasi belajar yang rendah. Masalah dengan dosen atau pengajar merupakan stresor tersendiri yang disebut sebagai stres konflik. Stres konflik dapat menyebabkan kelelahan emosional. ${ }^{17}$ Perkataan yang menyinggung perasaan dapat menyebabkan penurunan harga diri. Remaja yang menghargai dirinya cenderung lebih sedikit menunjukkan gejala GME. ${ }^{18}$

Semakin tinggi tingkat stres secara keseluruhan, semakin rendah motivasi belajar mahasiswa. $^{19}$ Rendahnya motivasi ini kemudian dapat menjadi stresor baru yang 
memperberat stres yang telah ada sebelumnya. Dalam taraf tertentu stres dibutuhkan dalam memfasilitasi belajar dan disebut sebagai 'favourable stres'. 8 Sebaliknya, stres yang berlebihan menekan pembelajaran dan dapat mengakibatkan berbagai masalah kesehatan baik fisik maupun mental. Secara umum, stres intrapersonal juga dilaporkan memiliki korelasi yang tinggi dengan gejala GME. ${ }^{20}$

\section{Domain TLRS}

Sumber utama stres akademik dengan tingkat berat-sangat berat yang dirasakan mahasiswa FK UPN "Veteran" Jakarta adalah kesulitan mencari referensi yang valid dan tidak yakin dengan hal yang dipelajari. KBK menerapkan strategi pembelajaran problem based learning (PBL). ${ }^{16}$ Model seperti ini mengharuskan mahasiswa mencari materi perkuliahan secara mandiri (prior knowledge) sebelum dihadapkan kepada suatu kasus pembelajaran. Mahasiswa harus menemukan referensi yang terpercaya dan berusaha memahami materi sebelum diajarkan dalam perkuliahan. Hal ini berpotensi menimbulkan salah pemahaman sehingga mahasiswa menjadi tidak yakin dengan pemahamannya sendiri. Kebanyakan orang mengalami keraguan diri pada suatu waktu tertentu, tetapi beberapa orang dapat mengalami keraguan berkepanjangan mengenai kemampuannya dan secara rutin merasa terbebani dengan pekerjaan yang harus dihadapinya. ${ }^{21}$ Apabila persepsi mengenai harga diri seseorang bergantung terhadap kemampuan dan kompetensi orang tersebut, maka keraguan terhadap diri sendiri dapat menyebabkan penurunan harga diri seseorang. ${ }^{21}$ Penurunan harga diri telah dikaitkan dengan timbulnya berbagai macam gejala gangguan mental. ${ }^{18}$

Pendidikan kedokteran belum dapat menyediakan lingkungan yang baik bagi mahasiswa kedokteran itu sendiri. ${ }^{3}$ Hal ini telah dibuktikan dengan fakta bahwa jumlah mahasiswa kedokteran yang terdiagnosis memiliki kecenderungan GME lebih tinggi dibandingkan populasi umum pada usia yang sama. ${ }^{22}$ Selain itu, cara mengajar dosen dan lingkungan belajar berpengaruh terhadap timbulnya tingkat stres yang signifikan. ${ }^{23} \mathrm{Hal}$ ini juga sesuai dengan sebuah penelitian yang melaporkan bahwa stresor kegiatan belajar mengajar berpeluang 2,7 kali untuk berkembangnya stres yang signifikan dan 2,8 kali untuk menyebabkan gejala depresif. ${ }^{20}$

\section{Domain SRS}

Sumber utama stres sosial dengan tingkat berat-sangat berat yang dirasakan mahasiswa FK UPN "Veteran" Jakarta adalah kurangnya waktu dengan teman dan keluarga serta ketakutan apabila suatu saat akan menghadapi kematian pasien. Banyak penelitian yang telah menghubungkan sedikit waktu bersama teman dan keluarga sebagai sumber stresor yang signifikan. $8,19,24$ Dukungan keluarga adalah strategi koping yang positif dalam menghadapi stres. ${ }^{10,25}$ Beberapa penelitian menunjukkan bahwa dukungan keluarga terutama orang tua berkorelasi negatif dengan angka GME dan sebaliknya, permasalahan dalam keluarga menyebabkan penurunan tingkat kesehatan mental. ${ }^{15,26}$

Kematian pasien merupakan stresor unik yang tidak ditemukan di jurusan perkuliahan lain selain kedokteran. ${ }^{24}$ Akan tetapi, stresor kematian pasien akan lebih relevan pada mahasiswa klinik dibandingkan preklinik. $^{3}$ Pada mahasiswa preklinik, pengaruh stresor tersebut adalah pikiran bahwa suatu saat diri mereka akan menghadapi kematian pasien menimbulkan ketakutan dan kecemasan.

\section{Domain DRS}

Sumber utama stres dorongan dan keinginan dengan tingkat berat-sangat berat yang dirasakan mahasiswa FK UPN "Veteran" Jakarta adalah ekspektasi orang tua serta mahasiswa yang sejak awal tidak ingin kuliah di fakultas kedokteran. Ekspektasi orang tua dapat berupa nilai akademik yang baik, prestise profesi atau gaji yang tinggi. ${ }^{3,27}$ Ekspektasi semacam ini dapat timbul karena orang tua telah mengeluarkan biaya yang banyak untuk menyekolahkan anaknya di 
fakultas kedokteran. ${ }^{15}$ Ekspektasi ini juga dapat muncul dari orang tua yang juga berprofesi sebagai dokter. Akan tetapi, beberapa penelitian yang meneliti pengaruh orang tua dokter dengan tingkat stres pada mahasiswa belum menemukan hasil yang seragam. ${ }^{5}$ Dukungan orang tua bersifat positif bagi mahasiswa, tetapi ekspektasi yang berlebihan dapat menjadi sumber stres yang signifikan. ${ }^{15,26}$

Mahasiswa yang memilih fakultas kedokteran akibat pengaruh tekanan luar memiliki kecenderungan GME yang tinggi. ${ }^{3}$ Menurut Pratiwi, hal ini disebabkan tujuan dan motivasi mahasiswa tidak dimulai dengan tekad dan kesungguhan. ${ }^{3}$ Tingkat stres domain DRS yang tinggi juga berhubungan dengan penurunan motivasi belajar. ${ }^{19}$ Rendahnya motivasi belajar dan ekspektasi orang tuayang berlebihan adalah sumber stres yang cukup signifikan dalam menimbulkan kecenderungan GME. $^{29}$

\section{Domain GARS}

Sumber utama stres aktivitas kelompok dengan tingkat berat-sangat berat yang dirasakan mahasiswa FK UPN "Veteran" Jakarta adalah merasa kurang kompeten dibandingkan teman satu kelompoknya serta timbulnya dorongan untuk menjadi lebih baik karena pengaruh teman satu kelompok. Dorongan ini timbul akibat membandingkan diri dengan teman kelompok, baik dilakukan oleh diri sendiri maupun orang lain seperti oleh pengajar. Kedua sumber stres tersebut dapat dianggap sebagai keraguan terhadap diri sendiri, yang berpotensi menurunkan harga diri dan menimbulkan gejala GME. ${ }^{21}$

Stres dalam aktivitas berkelompok dapat disebut sebagai stres kelompok (team stres). Team stres dapat diartikan sebagai hubungan antara suatu kelompok dengan lingkungannya, termasuk dengan sesama anggota, yang melelahkan, menghabiskan sumber daya dan membahayakan keberadaan kelompok tersebut. ${ }^{28}$ Sejalan dengan hasil penelitian ini, stres kelompok banyak diasosiasikan dengan timbulnya gejala-gejala GME. ${ }^{29}$

\section{KESIMPULAN}

Sebanyak 52 orang mahasiswa mengalami tingkat stres ringan-sedang dan 28 orang mengalami tingkat stres berat-sangat berat untuk stres secara umum. Pada tingkat sres untuk setiap domain stres didapatkan 35 orang mahasiswa mengalami tingkat stres berat-sangat berat pada domain ARS, 20 orang pada domain IRS, 18 orang pada domain TLRS, 12 orang pada domain SRS, 16 orang pada domain DRS dan 9 orang pada domain GARS. Domain ARS menyebabkan tingkat stres berat-sangat berat paling banyak dibandingkan domain lainnya.

Sebanyak 42 orang mahasiswa tidak memiliki kecenderungan GME dan 38 orang mahasiswa memiliki kecenderungan GME. Gejala GME yang paling dominan yaitu penurunan energi, diikuti ansietas, gejala somatik, gangguan kognitif dan depresi. Mahasiswa yang tidak memiliki kecenderungan GME juga menunjukkan gejala-gejala tersebut walaupun tidak mencapai nilai batas pisah dalam kuesioner.

Secara statistik dapat disimpulkan bahwa terdapat hubungan yang bermakna antara tingkat stres berat-sangat berat secara umum maupun setiap domain stresor dengan timbulnya kecenderungan GME pada mahasiswa FK UPN "Veteran" Jakarta. Domain yang paling berpengaruh adalah dorongan dan keinginan (DRS), akademik (ARS) dan hubungan intrapersonal dan interpersonal (IRS).

\section{DAFTAR PUSTAKA}

1. Abdulghani HM, Alkanhal AA, Mahmoud ES, Ponnamperuma GG, Alfaris EA. Stress and Its Effects on Medical Students: A Cross-sectional Study at a College of Medicine in Saudi Arabia. J Health Popul Nutr [Internet]. 2011;29(5):516-22. Available from: https://www.ncbi.nlm.nih.gov/pubmed/2 2106758.

2. Rahmayani RD, Liza RG, Syah NA. 
Gambaran Tingkat Stres Berdasarkan Stressor pada Mahasiswa Kedokteran Tahun Pertama Program Studi Profesi Dokter Fakultas Kedokteran Universitas Andalas Angkatan 2017. J Kesehat Andalas [Internet]. 2019;8(1):103-11. Available from: http://jurnal.fk.unand.ac.id/index.php/jk a/article/view/977

3. Sari AN, Oktarlina RZ, Septa T. Masalah Kesehatan Jiwa Pada Mahasiswa Kedokteran. J Medula [Internet]. 2017;7(4):82-7. Available from:

http://juke.kedokteran.unila.ac.id/index. $\mathrm{php} / \mathrm{medula/article/view/1694/pdf}$

4. Heinen I, Bullinger M, Kocalevent RD. Perceived stress in first year medical students - associations with personal resources and emotional distress. BMC Med Educ [Internet]. 2017;17(1):1-14. Available from: http://dx.doi.org/10.1186/s12909-0160841-8

5. Nivetha M. B, Ahmed M, B. P. Perceived stress and source of stress among undergraduate medical students of Government Medical College, Mysore. Int J Community Med Public Heal [Internet]. 2018;5(8):3513. Available from:

https://www.ijcmph.com/index.php/ijcm $\mathrm{ph} /$ article/view/3202

6. Wahyudi R, Bebasari E, Nazriati E. Gambaran Tingkat Stres pada Mahasiswa Fakultas Kedokteran Universitas Sumatera Utara. Jik [Internet]. 2015;9(2):107-13. Available from:http://repository.usu.ac.id/handle/1 23456789/25590

7. Lyon BL. Stress, Coping, and Health A Conceptual Overview. In: Handbook of Stress, Coping, and Health [Internet]. Sage Publications, Inc., 2012. hal. 2-20. Available from: https://pdfs.semanticscholar.org/dd0d/86 f56021211231f07d0fa4eb981a6891855f .pdf

8. Yusoff MSB, Rahim AFA, Yaacob MJ. Prevalence and Sources of Stress among Universiti Sains Malaysia Medical Students. Malaysian J Med Sci [Internet]. 2010;1(17):30-7. Available from: https://www.ncbi.nlm.nih.gov/pmc/articl es/PMC3216143/

9. Sidik SM, Rampal L, Kaneson N. Prevalence of emotional disorders among medical students in a Malaysian university. Asia Pac Fam Med [Internet]. 2003;2(4):213-7. Available from: https://onlinelibrary.wiley.com/doi/abs/1 0.1111/j.1444-1683.2003.00089.x

10. Zaid Z. Emotional disorders among medical students in a Malaysian private medical school. Singapore Med J [Internet].2007;48(10):895-9.Available from:

https://www.ncbi.nlm.nih.gov/pubmed/1 7909672

11. Widyahening IS. High level of work stressors increase the risk of mentalemotional disturbances among airline pilots. Med $\mathbf{J}$ Indones [Internet]. 2007;16(2):117. Available from: http://mji.ui.ac.id/journal/index.php/mji/ article/view/267

12. Novianty AS, Budiningsih S, Hidayat S. Hubungan Stres Kerja dengan Timbulnya Kecenderungan Gangguan Mental Emosional pada Perawat yang Terlibat Langsung dengan Penderita Gangguan Jiwa di Sebuah Rumah Sakit Jiwa di Jakarta. J Indon Med Assoc [Internet].2018;68(1):1-6. Available from:

http://mki.idionline.org/index.php?uPag $\mathrm{e}=$ mki.mki_dl\&smod=mki\&sp=public $\&$ key $=$ NDg0LTE1

13. Khan MS, Mahmood S, Badshah A, Ali SU, Jamal Y. Prevalence of Depression, 
Anxiety and their associated factors among medical students in Karachi, Pakistan. J Pakistan Med Assoc [Internet]. 2006;583-6. Available from: https://www.semanticscholar.org/paper/ Prevalence-of-depression\%2C-anxietyand-their-factors-Khan-

Mahmood/3f4c4201a725ba0e2f75325db 609eca6aac419d5

14. Cuttilan AN, Sayampanathan AA, Ho RC. Mental health issues amongst medical students in Asia : a systematic review [2000 - 2015]. Ann Transl Med [Internet]. 2016;4. Available from: https://www.ncbi.nlm.nih.gov/pmc/articl es/PMC4779785/

15. Saravanan C, Wilks R. Medical Students Experience of and Reaction to Stress: The Role of Depression and Anxiety. Sci World J [Internet]. 2014;2014:1. Available from:

http://dx.doi.org/10.1155/2014/737382

16. Fakultas Kedokteran Universitas Pembangunan Nasional "Veteran" Jakarta. Program Pendidikan Sarjana Kedokteran (PSSK) [Internet]. 2019 [dikutip 31 Desember 2019]. Available from: https://fk.upnvj.ac.id/id/programstudi/sarjana-kedokteran.html

17. Giebels E, Janssen O. Conflict Stress and Reduced Wellbeing at Work: The Buffering Effect of Third-Party Help. Eur J Work Organ Psychol [Internet]. 2004;14(2). Available from: https://www.researchgate.net/publicatio n/228181686_Conflict_Stress_and_Red uced_Wellbeing_at_Work_The_Bufferi ng_Effect_of_Third-Party_Help

18. Henriksen IO, Ranøyen I, Indredavik MS, Stenseng F. The role of self-esteem in the development of psychiatric problems: a three-year prospective study in a clinical sample of adolescents. Child Adolesc Psychiatry Ment Health [Internet]. 29 Desember 2017;11:68.
Available from:

https://www.ncbi.nlm.nih.gov/pubmed/2 9299058

19. Wahab S, Rahman FNA, Hasan WMHW, Zamani IZ, Arbaiel NC, Khor SL, et al. Stressors in secondary boarding school students : Association with stress , anxiety and depressive symptoms. AsiaPacific Psychiatry [Internet]. 2013;5:829. Available from: https://www.ncbi.nlm.nih.gov/pubmed/2 3857842

21. Zhao Q, Wichman A. Incremental Beliefs About Ability Ameliorate SelfDoubt Effects. Sage Publ [Internet]. 2015;5(4). Available from: https://journals.sagepub.com/doi/full/10. $1177 / 2158244015622539$

22. Maser B, Danilewitz M, Guerin E, Findlay L, Frank E. Medical Student Psychological Distress and Mental Illness Relative to the General Population: A Canadian Cross-Sectional Survey. Acad Med [Internet]. 2019;94(11):1781-91. Available from: https://www.ncbi.nlm.nih.gov/pubmed/3 1436626

23. Al-Dabal BK, Koura MR, Rasheed P, AlSowielem L, Makki SM. A Comparative Study of Perceived Stress among Female Medical and Non-Medical University Students in Dammam, Saudi Arabia. SQU Med J [Internet]. 2010;10(2):23140. Available from:

https://www.ncbi.nlm.nih.gov/pmc/articl es/PMC3074699/\# ffn_sectitle

24. Ghosal K, Behera A. Study on Prevalence of Stress in Medical Students. J Res Med Dent Sci [Internet]. 2018;6(5):182-6. Available from: https://www.jrmds.in/articles/study-onprevalence-of-stress-in-medicalstudents.pdf

25. Soliman M. Perception of stress and coping strategies by medical students at 
King Saud University, Riyadh, Saudi Arabia. J Taibah Univ Med Sci [Internet]. 2014;9(1):30-5. Available from:

http://www.sciencedirect.com/science/ar ticle/pii/S1658361213000814

26. Mustafa MB, Nasir R, Yusooff F.

Parental Support, Personality, SelfEfficacy and Depression among Medical Students. Procedia - Social and Behavioral Sciences [Internet]. 2010;7(2):419-24. Available from:

http://dx.doi.org/10.1016/j.sbspro.2010. 10.057

27. David MA, Evangeline SH. Stressors in health professional students. JETHS [Internet]. 2017;4(2):74-7. Available from:

https://www.innovativepublication.com/ journal-article-file/4847

28. Dietz AS, Driskell JE, Sierra MJ, Weaver SJ, Driskell T, Salas E. Teamwork under Stress. In: The Wiley Blackwell Handbook of the Psychology of Team Working and Collaborative Processes, First Edition [Internet]. 2017. hal. 297315. Available from:

https://www.researchgate.net/publicatio n/315438003_Teamwork_under_Stress 